\begin{tabular}{|c|c|}
\hline & $\begin{array}{l}\text { EDITOR } \\
\text { Susan Hassler } \\
\text { (New York) }\end{array}$ \\
\hline $\begin{array}{l}\text { RESEARCH EDITO } \\
\text { Harvey Bialy } \\
\text { (New York) }\end{array}$ & $\begin{array}{r}\text { ASSOCIATE } \\
\text { RESEARCH EDITOR } \\
\text { Philip Bernstein } \\
\text { (New York) }\end{array}$ \\
\hline ARTICLES EDITOR & NEWS EDITOR \\
\hline $\begin{array}{lr}\text { John Hodgson } \\
\text { (London) } & \text { SE } \\
& \text { Step }\end{array}$ & $\begin{array}{l}\text { NIOR EDITOR } \\
\text { (San Francisco) } \\
\text { hen M. Edgington } \\
\text { (New York) }\end{array}$ \\
\hline EDITO & $\begin{array}{l}\text { RIAL ASSISTANT } \\
\text { Emma Johnson } \\
\text { (London) }\end{array}$ \\
\hline $\begin{array}{r}\text { CONTR } \\
\text { Bernard Dixo } \\
\text { (Washington, D } \\
\text { George K } \\
\text { Kevin McC } \\
\text { Mima } \\
\text { Mike I }\end{array}$ & $\begin{array}{l}\text { IBUTING EDITORS } \\
\text { on (London); Jeffrey L. Fox } \\
\text { C.); Russ Hoyle (New York); } \\
\text { Kidd (Shorewood, WI); } \\
\text { Gough (Bronxville, NY); } \\
\text { Predich (New York); } \\
\text { Ward (Oxford, U.K.) }\end{array}$ \\
\hline $\begin{array}{l}\text { ART DIRECTOR } \\
\text { Lou Pippo }\end{array}$ & $\begin{array}{l}\text { ASST. ART DIRECTOR } \\
\text { Renée M. Roberts }\end{array}$ \\
\hline$\underset{\mathrm{Ja}}{\text { PRESID }}$ & $\begin{array}{l}\text { ENT \& PUBLISHER } \\
\text { mes Skowrenski }\end{array}$ \\
\hline VICE PI & $\begin{array}{l}\text { RESIDENT-SALES } \\
\text { Marion Delaney }\end{array}$ \\
\hline $\begin{array}{r}\text { ADVERTISI } \\
\text { Sano } \\
\text { Kathry } \\
\text { Bill Mo } \\
\text { Iain Jaw: }\end{array}$ & $\begin{array}{l}\text { NG SALES MANAGERS } \\
\text { de Giaccone (U.S.) } \\
\text { n Wayman (Europe) } \\
\text { ran (Classified, U.S.) } \\
\text { ad (Classified, Europe) }\end{array}$ \\
\hline MARK & $\begin{array}{l}\text { ETING DIRECTOR } \\
\text { Barbara Lande }\end{array}$ \\
\hline $\begin{array}{l}\text { MARKETING } \\
\text { MANAGERS }\end{array}$ & $\begin{array}{r}\text { PRODUCTION MANAGER } \\
\text { Estelle B. Selzer }\end{array}$ \\
\hline $\begin{array}{l}\text { Edelyn Enerio (U.S.) } \\
\text { Carolyn Hall (Europe) }\end{array}$ & $\begin{array}{r}\text { ASST. PRODUCTION } \\
\text { MANAGER } \\
\text { Lori R. Wankoff }\end{array}$ \\
\hline $\begin{array}{r}\text { PUBLIS } \\
\text { Al }\end{array}$ & $\begin{array}{l}\text { SHING DIRECTOR } \\
\text { ndy Sutherland }\end{array}$ \\
\hline EUROPEAN F & $\begin{array}{l}\text { PUBLISHING MANAGER } \\
\text { ohn Hodgson }\end{array}$ \\
\hline $\begin{array}{r}\text { 345 Park Avenue } \\
\text { Tel: } 1(212) 726 \\
\text { Editorial fax: } 1(212 \\
\text { E-mail: } b\end{array}$ & $\begin{array}{l}\text { NEW YORK } \\
\text { South, New York, NY 10010 } \\
\text {-9200 Fax: } 1 \text { (212) 696-9006 } \\
\text { 696-9635 MCI ID \#: 329-8956 } \\
\text { iotech@ natureny.com }\end{array}$ \\
\hline $\begin{array}{r}\text { Porter's South, C } \\
\text { Tel: } 44 \text { (171) } 833 \\
\text { E-mail: j.ho }\end{array}$ & $\begin{array}{l}\text { LONDON } \\
\text { rinan Street, London N1 9XW } \\
-4000 \text { Fax: } 44 \text { (171) 843-4998 } \\
\text { dgson @biotechnology.com }\end{array}$ \\
\hline $\begin{array}{l}\text { SCIENTIF } \\
\text { Leroy Hod (chair) } \\
\text { Ken-ichi Arai } \\
\text { Roger Beachy } \\
\text { Teruhike Beppu } \\
\text { Ronald E. Cape } \\
\text { Jean-Pierre Changeux } \\
\text { Mary-Dell Chitton } \\
\text { Nam-Hai Chua } \\
\text { Rita R. Colwell } \\
\text { Arnold Demain } \\
\text { J. Lawrence Fox } \\
\text { David Goeddel } \\
\text { Morio Itehara } \\
\text { Ernest Jaworski } \\
\text { Kary Mullis } \\
\text { Victor Nussenzweig } \\
\text { Gregory Petsko } \\
\text { George Poste } \\
\text { George Rose } \\
\text { Carl-Gustaf Rosen } \\
\text { Kendall Smith } \\
\text { Yukio Sugino } \\
\text { Marc Van Montagu } \\
\text { Indra K. Vasil } \\
\text { Wataru Yamaya } \\
\text { Douglas C. Youvan }\end{array}$ & $\begin{array}{l}\text { IC ADVISORY BOARD } \\
\text { University of Washington, Seattle } \\
\text { University of Tokyo } \\
\text { Scripps Research Institute } \\
\text { Nihon University } \\
\text { Darwin Molecular Corporation } \\
\text { Institut Pasteur } \\
\text { CIBA-Geigy } \\
\text { Rockefeller University } \\
\text { Maryland Biotechnology Institute } \\
\text { Massachusetts Institute of Technology } \\
\text { Amoco Technology } \\
\text { Tularik } \\
\text { Protein Engineering Research Institute } \\
\text { Monsanto Company } \\
\text { Consultant } \\
\text { New York University Medical Cir } \\
\text { Brandeis University } \\
\text { SmithKline Beecham } \\
\text { Washington University } \\
\text { Abitec AB } \\
\text { New York Hospital/Cornell Medical Ctr } \\
\text { Takeda Chemicals } \\
\text { University of Ghent } \\
\text { University of Florida } \\
\text { Seikagaku Kogyo } \\
\text { KAIROS Scientific Inc. }\end{array}$ \\
\hline
\end{tabular}

ITHE FIRST WORD

\section{Bio/Technology to become Nature Biotechnology}

I

n March of this very new year, Bio/Technology will expand its peer-reviewed research section and become Nature Biotechnology. It will look different, more 1 journal-like in its demeanor, and we hope, be easier to read. What this means substantively is that we will be able to broaden and deepen the amount and kind of research we publish. This renewed focus on research will also be reflected in the news and features sections, which will continue to be essential components of the journal.

Why are we becoming Nature Biotechnology? The decision was not taken lightly. When Bio/Technology began publication in March 1983, there was more in the way of good intentions than research going on. But now, when there is an extraordinary amount of high-quality research underway, it has become clear that it is time to reemphasize that it is the journal of the research technologies that drive innovation wherever biotechnology is put to use. Central to our decision to become Nature Biotechnology was the fact that, in all our surveys, you, our readers, ranked advances in research as the most significant force in the development of biotechnology. And the most significant force in your working lives. And the most significant subject you would like to read about in these pages.

And who exactly are you? One answer is a broad and international audience of biologists, biochemists, biophysicists, and bioengineers, working primarily in research or in research and development. A significant minority are in senior commercial and administrative positions within biotechnology or biotechnologyrelated companies. But the truest answer is anyone who uses, or thinks about the use of, the tools of modern biology to address the real-world problems confronted by the biotechnology, pharmaceutical, and agricultural, among many other, industries.

As noted in our call for papers (p. 27), Nature Biotechnology will extend the efforts begun by Bio/Technology, seeking out and publishing peer-reviewed research reports and reviews from the best industrial and academic laboratories around the world. Research published in Nature Biotechnology will begin at the level of basic mechanism and extend all the way to commercial realization. Rapid publication after peer review, already a mainstay of the research section, will continue.

In addition to more research, Nature Biotechnology will continue to bring you the news and features that you have come to expect from Bio/Technology. Nature Biotechnology will be for scientists who know their business. Their main business, certainly, is research, but it is a rare lab these days that practices only pure, knowledge-oriented research and can support all its efforts with government funding. Thus, commercial and regulatory developments and the interactions between them and the research community are crucial; no working scientist can afford to be uninformed about the business of science. All research occurs in a social and economic context, and we plan to bring you that context as best we are able. In addition to its important archival function, we see Nature Biotechnology as a vital organ of dialogue about biological research, the ways it is used as technology, and the ways those technologies become commercial realities.

I believe you will be pleased, as both readers and potential authors, with the changes you will find in the March 1996 issue. Editorial staff members both in New York and in London are very enthusiastic about the opportunity to bring you more research and more research news. Innovation, in research and in business, will be the key to success in the 21st century-and Nature Biotechnology will specialize in such innovation.

Over the past 13 years, Bio/Technology has set the standard for the publication of significant research results in the many disciplines that encompass present-day industrial biology. In officially identifying ourselves with the other journals of the Nature group, we are embracing a 126-year tradition of excellence both in research and in science journalism. We intend to contribute our share to its continuity.

-SUSAN HASSLER

E-mail: s.hassler@natureny.com 